\title{
THE DIVERSITY CHALLENGE
}

\author{
Lawrence D. Bobo \\ Department of Sociology and of African and African American Studies, \\ Harvard University
}

To characterize U.S. politics today as polarized is to state the obvious. Nevertheless, Barack Obama's election as the forty-fourth and first African American president of the United States in 2008 had an air of inevitability to it. The presidency of George W. Bush was at that point widely regarded as a profound failure. His administration had mishandled two on-going wars, brought us the nationally humbling debacle of hurricane Katrina, and took us to the brink of economic collapse. And thus the Democratic party nominee for president, who happened to be Black, was handily elected with $53 \%$ of the popular vote, carrying twenty-eight states and with some 365 electoral college votes.

The issues that defined the 2008 agenda for then candidate Obama involved changing the climate of acrimony and paralysis in Washington, a commitment to responsibly end the Bush wars in Iraq and Afghanistan, to finally move toward real universal health care provision in the United States, and to act expeditiously to prevent the Great Recession from becoming another Great Depression. The Obama administration acted on all of these fronts. But in some respects it was the successful passage of the Affordable Health Care Act, henceforth Obamacare, that fully re-kindled the flames of antagonism and polarization. The spasm of reaction against Obamacare, epitomized by the emergence of the Tea Party, revealed the deep fissures of ideology, class, and race-with race arguably the most prominent among these-that define the current political context.

Why would a president who had won election handily, who preached a mantra of bipartisanship and cooperation, and who then delivered on one of the most central and explicit tenets of his campaign become a leader who the opposition party publicly, and arguably irresponsibly, dedicated itself to making "a one term president," essentially no matter what? The elements of how to go about crafting an answer to this deceptively simple question are many and complex and reach well beyond the scope of this essay. However, it is certainly fair to assert that one of the central elements of any answer concerns the profound and ramifying effects of ethnoracial divisions in the American polity. 


\section{Lawrence D. Bobo}

For two decades, scholars have been discussing the implications of a changing U.S. population. The broader political implications and effects of the rising proportion of the population that hails from traditional ethnic minority communities are increasingly felt quite directly in the ballot box. In an interesting series of experiments, a team of social psychologists showed that when primed with information about impending demographic transition in which Whites would become a minority, Whites expressed greater anger at and feelings of threat from ethnoracial minorities, and expressed greater in-group cohesion (Outten et al., 2012).

More than ever before, the 2012 presidential election campaign season forced recognition of just how centrally the racial divide defines the current American party system and traditional presidential voting patterns. Obama won in 2008 with only $42 \%$ of the White vote, but nearly two-thirds of the Latino and Asian vote and a hypermajority (more than 95\%) of the African American vote. In 2012, his percentage of the White vote declined to $38 \%$, but increased for both Asian and Latino votes, while (perhaps) slightly declining among African Americans to $93 \%$. Although overall turnout was slightly lower in 2012 than in 2008 (roughly 58\% versus 62\%), Obama still secured a solid victory carrying 50.6\% of the vote, twenty-six states and 332 electoral votes. Surprisingly to some observers, this included carrying nine of the ten so-called swing states, including Florida and Virginia.

There will be debates for some time over the meaning of Obama's successful run for a second term. The source of his success has variously been credited to Latino voters, to Black voters, to "urban" turn out, to Obama's provision of "gifts" to different segments of the electorate, to better organization at the grass-roots level, to better use of the internet and social media, to a weak Republican nominee, to a liberal bias in the media, to hurricane Sandy, and more. The United States re-elected an incumbent who not only faced unemployment at roughly $8 \%$ but who was out-spent significantly by his Republican adversaries. It is hard not to read this as signaling something about the deeper structure of the American electorate and its social fabric.

One of the core features of that deeper structure is a racialized social order. This order is not static, but dynamic and evolving. From the outset, the ambition of this journal has been to reveal, better conceptualize, theorize, and understand precisely these types of phenomena. The material in this issue continues to press toward an ever richer understanding of these shifting social forces.

Distinguished sociologist Herbert J. Gans develops a detailed argument about the research now needed to illuminate the process of Whitening. In part, the essay can be read as a modification of an earlier hypothesis he offered that the United States was evolving away from the traditional Black-White divide and toward a Black/non-Black dichotomy (Gans 1999). Now he suggests that the more analytically central issue is that of who is admitted to Whiteness, with the end points of polar extremes of Whiteness and Blackness, privilege and valorization, on the one hand, and disadvantage and stigma still well in place on the other, with signs of enormous fluidity in between.

Former U.S. Census Bureau director and eminent social scientist Kenneth Prewitt raises some tough questions about the extent of our reliance on conventional race categories. To a degree the essay is about appropriate and inappropriate statistical uses of racial nomenclature for purposes of counting and description. In particular, he challenges the sometimes quite distorting imposition of a racial lens on phenomena that may not be effectively described by such a scheme. Pivoting off of 
the historical lesson of claims of race-based undercount in the Census, where factors other than race are actually more central to the problems of Census coverage, Prewitt raises serious questions about the imposition of race labels and categories on scientific and medical developments linked with human genome research. He points to troubling ways in which a re-biologizing of notions of race is underway.

If the process of selective admission to Whiteness is still very much alive and if biology is making a comeback in terms of scientific conceptions of race, ${ }^{1}$ then there may be, more than ever, a pressing need for a progressive politics of race. In this regard, sociologist William Julius Wilson and political scientist Michael C. Dawson are featured in a robust conversation about the future of Black politics. At the center of their exchange is the question of how to best tackle the deeply intertwined issues of broader economic inequality and race specific inequality. They engage the question of the priority that ought to be placed on universalistic versus race-targeted social policies; the impact of immigration on Black aspirations and politics; and the role of Black leadership, especially the Obama administration, in advancing policies needed by disadvantaged minority communities.

This issue of the Du Bois Review also contains a special section of articles, edited by historian Ramón Gutiérrez on "Race and Immigration in the American City." Gutiérrez provides a separate and detailed introduction to the six well-crafted research articles features in that section. This new and innovative work does much to highlight the complex relationship among the growing Latino community and the African American population, especially the places and ways that the experiences of the two groups coincide as well as diverge economically and politically.

In our State of the Art section political scientist Daniel Kato makes a provocative argument about the capacity of the state to address racial violence. He challenges a simple view of state weakness as the lack of authority or resources to prevent racial violence. His research suggests that the state was more of an implicit collaborator in lynching and other like violence rather than an immobilized or strapped observer. The work casts a different and harsh light on when and for whom the state extends full membership in the polity.

Sociologists Maryann Erigha and Camille Z. Charles look back on the nature of racial appeals during the 2008 presidential campaign. They conduct content analyses of a large number of advertisements from both major political parties. They find that Republican advertisements implicitly invoked racial stereotypes whereas Democratic campaign advertisements largely avoided or de-emphasized racial difference. If there was a point of bipartisan unity it involved the avoidance of racially explicit appeals by both parties.

It is true that a multiracial coalition returned Barack Obama to the White House for a second term. There are good reasons to regard this as a portentous development. Yet, it is also clear that matters of ethnoracial division will continue to be contentious issues in American politics and social life, as the contents of the Du Bois Review make clear. These matters of the evolution of Whiteness, when to use and when to eschew race categories, the search for a progressive politics of race, the complex interweaving of the lives of Blacks and Latinos in the United States, the role of the state, and how political campaigns manipulate and deploy racial symbols are all important but do not exhaust the ways in which race shapes our sociopolitical lives.

\section{NOTE}

1. There is good reason to wonder if the social constructionist view of race ever reaches very far beyond the social science elite (Morning 2011). 


\section{Lawrence D. Bobo}

\section{REFERENCES}

Gans, Herbert (1999). The Possibility of a New Racial Hierarchy in the Twenty-First Century United States. In Michele Lamont (Ed.), The Cultural Territories of Race: Black and White Boundaries, pp. 371-390. Chicago, IL and New York: University of Chicago Press and Russell Sage Foundation.

Morning, Ann (2011). The Nature of Race: How Scientists Think and Teach About Human Difference. Berkeley, CA: University of California Press.

Outten, H. Robert, Michael T. Schmitt, Daniel A. Miller, and Amber L. Garcia (2012). Feeling Threatened about the Future: Whites' Emotional Reactions to Anticipated Demographic Changes. Personality and Social Psychology Bulletin, 38(1): 14-25. 